\title{
Efficacy of methyl bromide used at reduced rates to control larvae and adults of goldenhaired bark beetle, Hylurgus ligniperda
}

\author{
K.G. Somerfield ${ }^{1}$, B.L. Bycroft ${ }^{1}$, D.W. Brash ${ }^{1}$, J.N. Clark ${ }^{1}$, D.I. Hedderley ${ }^{1}$ \\ and J.W. Armstrong ${ }^{2}$ \\ ${ }^{1}$ The New Zealand Institute for Plant \& Food Research Limited, Private Bag 11600, \\ Palmerston North, New Zealand \\ ${ }^{2}$ Quarantine Scientific Limited, P.O. Box 408204, Kerikeri East 0248, New Zealand \\ Corresponding author:Ken.Somerfield @plantandfood.co.nz
}

\begin{abstract}
Pine (Pinus radiata D. Don) logs exported from New Zealand must undergo fumigation to ensure they are free of phytosanitary insects to meet the requirements of importing countries. The goldenhaired bark beetle, Hylurgus ligniperda (F.), is one of the major hitch-hiker species that can infest New Zealand pine logs. Adults and larvae can be present in the bark and cambium layer of freshly cut logs. To examine ways of reducing rates of methyl bromide fumigation, diet containing both life stages (extracted from pine logs) was exposed to 0,49 or $73 \mathrm{~g} / \mathrm{m}^{3}$ methyl bromide for $16 \mathrm{~h}$ in 28 -litre fumigation chambers at $5,10,15$ or $20^{\circ} \mathrm{C}$. Both the $49 \mathrm{~g} / \mathrm{m}^{3}$ and $73 \mathrm{~g} / \mathrm{m}^{3}$ methyl bromide exposures resulted in $100 \%$ mortality at all temperatures. Average mortality among controls was: larvae $7 \%$, adults $23 \%$. The results indicate that the present methyl bromide fumigation rates used for pine logs exported from New Zealand could be reduced.
\end{abstract}

Keywords methyl bromide, fumigation, pine logs, Pinus radiata D. Don, quarantine treatments.

\section{INTRODUCTION}

The New Zealand Government (as Party to the Montreal Protocol) and the public have become increasingly concerned about the use of methyl bromide to fumigate export pine (Pinus radiata D. Don) logs. Methyl bromide use in New Zealand increased from 270 tonnes in 2009 to 406 tonnes in 2010 (New Zealand Ministry for the Environment 2011). The increase in methyl bromide use is due solely to an increase in log trade to countries that require fumigation (United Nations Environment Programme 2010). In response to safety concerns, controls on the use of methyl bromide have become more stringent regarding buffer zones around fumigation locations (New Zealand Environmental Protection Authority 2011). Additionally, total recapture or destruction of methyl bromide after fumigation will be required by 2020 to ensure no fumigant escapes into the atmosphere. Other methods to reduce the amount of methyl bromide used to fumigate logs are being studied, including research to accurately define the optimum amount of methyl bromide required to control pests on export logs.

Insects of major quarantine importance include the goldenhaired bark beetle, Hylurgus ligniperda 
(F.) (Coleoptera: Scolytidae); the black pine bark beetle, Hylastes ater (Paykull) (Coleoptera: Scolytidae); and the burnt pine longhorn beetle, Arhopalus ferus (Mulsant) (Coleoptera: Cerambycidae).

Hylurgus ligniperda is native to central Europe, Asia and Mediterranean regions but it has established in numerous countries including Japan, Sri Lanka, South Africa, Brazil, Chile, North America, Australia and New Zealand (Haack 2001). First recorded in New Zealand in 1974, H. ligniperda adults are 7-8 $\mathrm{mm}$ in length, $2 \mathrm{~mm}$ in width and black in colour (Bain 1977), and today generally comprise over $90 \%$ of all bark beetle populations in New Zealand pine forests (Bain 1977; Reay \& Walsh 2001; Brockerhoff et al. 2006).

The predominant host in New Zealand for H. ligniperda is Pinus species (Lee et al. 2007). Adults breed in freshly dead host material including cut stumps, logs and debris from trees after harvest. Hylurgus ligniperda is bivoltine with two generations per year that correspond to two peaks of adult flight activity - one during spring and the other during autumn. The immature stages are easily transported on unprocessed logs or lumber, packing materials, pallets and dunnage. One of the current treatments used to provide quarantine security against these pests is fumigation with methyl bromide.

Comparison of the methylbromide fumigation schedules for pine logs from New Zealand shows that the dose rates required by three Asian trading partners differ significantly (Table 1). Two different temperature regimes are specified according to the ambient air temperature at the time of fumigation. Temperatures below $15^{\circ} \mathrm{C}$ require higher dose rates to have the same efficacy as treatments above $15^{\circ} \mathrm{C}$ within the specified 16 or $24 \mathrm{~h}$ fumigation times.

Table 1 shows methyl bromide application rates that vary from $72.5 \mathrm{~g} / \mathrm{m}^{3}$ (Japan) to $120 \mathrm{~g} / \mathrm{m}^{3}$ (China) for temperatures $\leq 15^{\circ} \mathrm{C}$ and from $33 \mathrm{~g} /$ $\mathrm{m}^{3}$ to $80 \mathrm{~g} / \mathrm{m}^{3}$ for temperatures above $15^{\circ} \mathrm{C}$ with the highest rates required for logs exported to China.

Based on historical data and statistical analyses of the available methyl bromide efficacy information for New Zealand log pests, Armstrong et al. (2011) recommended that the current methyl bromide rates could be reduced to $49 \mathrm{~g} / \mathrm{m}^{3}$ or $73 \mathrm{~g} / \mathrm{m}^{3}$ for fumigations at $15^{\circ} \mathrm{C}$ or $15^{\circ} \mathrm{C}$, respectively, for $16 \mathrm{~h}$ fumigations. However, the rate reductions recommended by Armstrong et al. (2011) must be tested under controlled conditions to demonstrate that the lowered rates will provide quarantine security against the target pests.

This paper presents the results of assays to establish the efficacy of methyl bromide fumigation, delivered at the two concentrations recommended by Armstrong et al. (2011), against H. ligniperda adults and larvae at temperatures ranging from $5^{\circ} \mathrm{C}$ to $20^{\circ} \mathrm{C}$.

\section{MATERIALS AND METHODS Preparation of insects}

Pine logs (50-60 cm long and 12-30 cm diameter) were infested with $H$. ligniperda several months before tests were initiated to provide larvae and

Table 1 Methyl bromide log fumigation schedules specified by China (Ministry for Primary Industries 2012) at export, and by Japan (Plant Protection Station, MAFF Japan 2011) and Korea (Yu et al. 1984) at import at two different fumigation temperatures above or below $15^{\circ} \mathrm{C}$.

\begin{tabular}{lccc}
\hline Country & Temperature $\left({ }^{\circ} \mathrm{C}\right)$ & MeBr rate $\left(\mathrm{g} / \mathrm{m}^{3}\right)$ & Time $(\mathrm{h})$ \\
\hline China & $\geq 15$ & 80.0 & 16 \\
Japan & $\geq 15$ & 48.5 & 16 \\
& $\geq 15$ & 33.0 & 24 \\
Korea & $\geq 15$ & 49.5 & 16 \\
China & $\leq 15$ & 120 & 16 \\
Japan & $\leq 15$ & 72.5 & 16 \\
\hline
\end{tabular}


adults from the same cohort for each test. The infested logs were stored in a humidity- and temperature-controlled room at $11^{\circ} \mathrm{C}$ until 8 weeks before testing, when the temperature was increased to $14^{\circ} \mathrm{C}$ to facilitate the development of larvae through to adults. Relative humidity was held at $70 \% \pm 5 \%$ during storage to prevent the insects from desiccating.

Hylurgus ligniperda larvae and adults were obtained by removing the logs from storage and prising the bark off each log using screwdrivers. The frass and debris from the inside of the bark and from the surface of the log were swept into a tray using a hearth brush. The insects were hand-sorted from the frass and debris, and temporarily held in plastic tubs lined with a layer of moistened paper towel to prevent desiccation.

An artificial bark diet for larvae and adults was made from pieces $(2-3 \mathrm{~cm}$ diameter) of pine bark. The bark was pulverised in a blender at low speed and the ground bark was sieved through $2.36 \mathrm{~mm}$ and $1.18 \mathrm{~mm}$ Endecott sieves. Bark particles ( 1.18 to $2.36 \mathrm{~mm})$ were mixed $(2: 1 \mathrm{vol} /$ vol) with fine bark particles $(\leq 1 \mathrm{~mm})$. The bark particles were sprayed with distilled water and mixed until uniformly moist.

Clear plastic screw-top containers $(200 \mathrm{ml}$ volume) were used to hold the larvae or adults during fumigation tests. Each container had a $30 \mathrm{~mm}$ diameter hole cut into the lid and the base. The holes were secured with a circular piece of stainless steel mesh (30 mesh/inch) that was heat-sealed in place to allow gas exchange but prevent the insects from escaping. Separate containers, laid on their side, were used for larvae or adults. Five grams of the moist bark diet was placed in a layer inside each container. Larvae or adults (40-50 healthy individuals of mixed age) were placed on top of the diet. A piece of moistened paper towel was placed on top of each insect/diet mix to maintain humidity. Lids were then screwed on the containers. The containers were kept on their side during fumigation to facilitate gas circulation, and remained on their side until post-fumigation mortality assessment was completed.

\section{Treatment procedure}

Fumigations were done in 28-litre chambers consisting of modified vacuum desiccators (Model 55300-00, Labconco, Kansas City, Missouri, USA) fitted with circulation fans to mix the atmosphere within the chamber and customised door clamps to eliminate leakage. In addition to the insects, a data logger (Temprecord Scientific Recorder ILTE-953101C, Temprecord International Limited, Auckland, NZ) was placed in each chamber to monitor temperature. A vacuum (approximately $-30 \mathrm{kPa}$ ) was drawn from each chamber. The vacuum facilitated the introduction of calculated amounts (up to $500 \mathrm{ml}$ ) of pure methyl bromide gas into each chamber using a 1-litre syringe (Model S1000, Hamilton Company, Reno, Nevada, USA). After the methyl bromide was introduced, each chamber was returned to normal atmospheric pressure. The atmosphere within the chambers was mixed for $5 \mathrm{~min}$. They were then placed in a temperature-controlled room at $5,10,15$ or $20^{\circ} \mathrm{C}$ (Table 2).

Each methyl bromide dose rate and treatment temperature combination was replicated three times (three separate containers). All fumigations were $16 \mathrm{~h}$ in duration. Treatments at each temperature were carried out on separate days.

The data loggers showed that temperatures in the chambers at 15 and $20^{\circ} \mathrm{C}$ were accurate to within $1^{\circ} \mathrm{C}$ throughout the trial. For 5 and $10^{\circ} \mathrm{C}$ treatments temperatures were initially up to $6^{\circ} \mathrm{C}$ higher than required while chambers cooled down during the first $3 \mathrm{~h}$.

Table 2 Temperatures and methyl bromide dose rates used in fumigations of $H$. ligniperda larvae and adults. The ' $\checkmark$ ' shows treatments included in this study.

\begin{tabular}{lccc}
\hline \multirow{2}{*}{$\begin{array}{l}\text { Temperature } \\
\left({ }^{\circ} \mathrm{C}\right)\end{array}$} & \multicolumn{3}{c}{ Methyl bromide dose $\left(\mathrm{g} / \mathrm{m}^{3}\right)$} \\
\cline { 2 - 4 } 5 & 0 & 49 & 73 \\
10 & $\checkmark$ & & $\checkmark$ \\
15 & $\checkmark$ & $\checkmark$ & $\checkmark$ \\
20 & $\checkmark$ & $\checkmark$ & $\checkmark$ \\
\hline
\end{tabular}


At completion of fumigation the chambers were aerated for 15 min using a vacuum pump, doors were opened and the containers of insects and the data loggers were removed.

\section{Fumigant monitoring}

Methyl bromide concentrations in the chambers were monitored by collecting duplicate $3 \mathrm{ml}$ samples with a gas-tight syringe. The samples were analysed with a SRI 8610C gas chromatograph equipped with a flame ionisation detector (FID) and a J\&W GS-Q $30 \mathrm{~m} \times 0.53$ $\mathrm{mm}$ column. Chromatography conditions were: oven temperature isothermal at $100^{\circ} \mathrm{C}$, carrier gas helium at $45 \mathrm{PSI}, \mathrm{FID}$ at $300^{\circ} \mathrm{C}$ and injector temperature at $250^{\circ} \mathrm{C}$.

In initial tests, methyl bromide concentration measurements were completed shortly after the chamber was returned to normal atmospheric pressure, and again at 2, 4, 8 and $16 \mathrm{~h}$ during and at the end of each fumigation. In later tests, methyl bromide concentrations were measured shortly after atmospheric equilibration and at 2, 4 and $16 \mathrm{~h}$ because GC analysis showed the methyl bromide concentrations did not change significantly during fumigation.

\section{Mortality assessment}

After removal from the fumigation chambers, the plastic containers were aerated for $24 \mathrm{~h}$ under a fume hood (air flow $0.1-0.15 \mathrm{~m} / \mathrm{s}$ measured with Airflow TA 3000, Airflow Developments Ltd., High Wycombe, Buckinghamshire HP12 3QP, England.). Larvae and adults were then removed from each container and counted. Insects showing little or no movement (either moribund or only immobile) were placed in a Pyrex ${ }^{\circledR}$ Petri dish (with lid fitted) and the Petri dish was held for up to $1 \mathrm{~min}$ on a temperature-controlled hot plate at $42.5^{\circ} \mathrm{C}$. Insects previously showing no activity began moving quickly while dead insects did not respond to the heat stimulus.

\section{Statistical analysis}

Mortality percentages were compared using binomial generalized linear models, with allowance for overdispersion where necessary. Analysis was done in Genstat (Version 15, 2012, VSNi Ltd, UK)

\section{RESULTS}

\section{Methyl bromide concentrations}

Gas concentrations in the chambers were within $2.6 \mathrm{~g} / \mathrm{m}^{3}$ of the target concentration with two exceptions: the methyl bromide concentration in one $10^{\circ} \mathrm{C}$ fumigation was consistently $7.1 \mathrm{~g} / \mathrm{m}^{3}$ above the $73 \mathrm{~g} / \mathrm{m}^{3}$ target concentration, and in another $10^{\circ} \mathrm{C}$ fumigation the methyl bromide concentration was consistently $6.2 \mathrm{~g} / \mathrm{m}^{3}$ below the $49 \mathrm{~g} / \mathrm{m}^{3}$ target concentration. Methyl bromide loss in all chambers during the $16 \mathrm{~h}$ fumigation was no greater than $8.6 \%$ of their initial dose.

\section{Insect mortality}

Methyl bromide doses of 49 or $73 \mathrm{~g} / \mathrm{m}^{3}$ both killed $100 \%$ of $H$. ligniperda larvae and adults at all temperatures (Table 3). Mortality in the control chambers varied between $3-16 \%$ for larvae and $4-34 \%$ for adults (Table 3). Mortality from methyl bromide was significantly higher $(\mathrm{P}<0.001$ for adults and larvae at all temperatures except for adults fumigated at $15^{\circ} \mathrm{C}$ where $\mathrm{P}=0.002$ ). When comparing mortality according to temperature, it was not possible to separate out methyl bromide dose from temperature due to the complete mortality. In the untreated controls, adults had significantly higher mortality at 5 and $10^{\circ} \mathrm{C}$ compared to larvae $(\mathrm{P}=0.031$ and 0.019 , respectively).

\section{DISCUSSION}

Although there was an initial delay in achieving the target temperatures in the $5^{\circ} \mathrm{C}$ and $10^{\circ} \mathrm{C}$ treatments, the target temperature was achieved within $3 \mathrm{~h}$ after the treatments were initiated and were accurate thereafter. Delay in achieving the target temperatures was caused by the time required to draw the vacuum on the chambers and add and mix the fumigant at ambient temperature, then cool the fumigation chambers to 5 or $10^{\circ} \mathrm{C}$.

Doses of methyl bromide used in the tests were accurate because of the low loading factor (between one and three small containers in a 28-litre chamber). Amounts of material in the chambers were too small for sorption to occur, and the well-sealed chambers prevented any loss of methyl bromide.

The $5 \mathrm{~g}$ of bark diet in each container was sufficient to maintain the insects during the 16-h 
Table 3 Mean and SE for mortality (\%) of H. ligniperda larvae and adults fumigated with 0, 49 or $73 \mathrm{~g} /$ $\mathrm{m}^{3}$ methyl bromide at $5,10,15$ or $20^{\circ} \mathrm{C}$.

\begin{tabular}{|c|c|c|c|c|c|c|c|}
\hline \multirow{2}{*}{$\begin{array}{l}\text { Temperature } \\
\left({ }^{\circ} \mathrm{C}\right)\end{array}$} & \multirow{2}{*}{$\begin{array}{c}\text { Dose } \\
\left(\mathrm{g} / \mathrm{m}^{3}\right)\end{array}$} & \multicolumn{3}{|c|}{ Adults } & \multicolumn{3}{|c|}{ Larvae } \\
\hline & & Mean & SE & $\mathrm{n}$ & Mean & SE & $\mathrm{n}$ \\
\hline 5 & 0 & 25 & 7 & 149 & 3 & 2 & 150 \\
\hline 5 & 73 & 100 & 0 & 149 & 100 & 0 & 150 \\
\hline 10 & 0 & 28 & 7 & 120 & 3 & 2 & 150 \\
\hline 10 & 49 & 100 & 0 & 120 & 100 & 0 & 150 \\
\hline 10 & 73 & 100 & 0 & 120 & 100 & 0 & 150 \\
\hline 15 & 0 & 34 & 18 & 152 & 6 & 0 & 149 \\
\hline 15 & 49 & 100 & 0 & 144 & 100 & 0 & 150 \\
\hline 15 & 73 & 100 & 0 & 151 & 100 & 0 & 149 \\
\hline 20 & 0 & 4 & 3 & 150 & 16 & 3 & 120 \\
\hline 20 & 49 & 100 & 0 & 150 & 100 & 0 & 119 \\
\hline
\end{tabular}

trial and facilitated the rapid retrieval of insects after each fumigation. The piece of paper towel remained moist throughout the fumigation and post-treatment mortality assessments. Mortality of adults and larvae in the controls was probably not due to desiccation as humidifiers were provided. Average adult mortality was $22.5 \%$ and average larval mortality was $7.1 \%$. Adult H. ligniperda had significantly higher mortality than larvae at 5 and $10^{\circ} \mathrm{C}$. Hylurgus ligniperda larvae may be more cold tolerant, or this difference may reflect the effect of other control conditions on survival of each life stage, such as relative acceptability of diet, average age of each life stage, or other factors.

Fumigation is likely to occur over a range of temperatures in New Zealand, and may be below $10^{\circ} \mathrm{C}$ in winter. The USDA Treatment Manual (USDA 2012) allows for methyl bromide fumigation over a wide range of temperatures with $4.4^{\circ} \mathrm{C}$ being the lowest allowed because vaporization becomes increasingly difficult at conditions below $4.4^{\circ} \mathrm{C}$. The present results show that methyl bromide is effective at $5^{\circ} \mathrm{C}$. Temperatures close to $5^{\circ} \mathrm{C}$ or less are likely to occur in winter in the South Island. Barak et al. (2011) found that ash (Fraxinus spp.) logs fumigated with $112 \mathrm{~g} / \mathrm{m}^{3}$ methyl bromide at $4.4^{\circ} \mathrm{C}$ resulted in complete mortality of fully-developed larval and pre- pupal emerald ash borer, Agrilus plannipennis Fairmaire (Coleoptera: Buprestidae). The effect of methyl bromide may vary with the life stage of the insect species being treated. In the present study complete mortality of larval and adult $H$. ligniperda was achieved. Vincent \& Lindgren (1977) fumigated cigarette beetle, Lasioderma serricorne (F.) (Coleoptera: Anobiidae), life stages with methyl bromide and found that the 5-day-old cocoons (predominantly pupae and prepupae) were most tolerant to methyl bromide at $4.4-10.0^{\circ} \mathrm{C}$ but that 1-day-old cocoons containing only larvae were most tolerant at $15.6^{\circ} \mathrm{C}$ or $21.1^{\circ} \mathrm{C}$. Increased exposure times at decreasing temperatures to obtain complete mortality for fruit fly eggs and larvae fumigated with methyl bromide in the range of $15-30^{\circ} \mathrm{C}$ were reported by Armstrong \& Whitehand (2005). Vincent \& Lindgren (1975), Bond (1975) and Bond \& Buckland (1976) also described the need to increase fumigant times or dose rates to achieve required mortality as temperatures decreased.

Results given here are a first step towards optimising methyl bromide dose rates for control of forest pests on export logs.

\section{CONCLUSIONS}

Methyl bromide was effective for controlling $H$. ligniperda adults and larvae directly exposed 
to the fumigant, and the efficacy of dose rates lower than those currently being required by some overseas markets was demonstrated.

\section{ACKNOWLEDGEMENTS}

We thank Steve Pawson, Scion, Rotorua, for infested logs, and Stakeholders in Methyl Bromide Reduction Inc. and the Ministry for Business, Innovation and Employment Primary Growth Partnership for funding the research reported herein.

\section{REFERENCES}

Armstrong JW, Brash D, Hall A, Waddell BC 2011. Standardisation of methyl bromide use for New Zealand log exports. Plant \& Food Research Report No 6242. Plant \& Food Research, Palmerston North, New Zealand. 14 p.

Armstrong JW, Whitehand LC 2005. Effects of methyl bromide concentration, fumigation time, and fumigation temperature on Mediterranean and oriental fruit fly (Diptera: Tephritidae) egg and larval survival. Journal of Economic Entomology 98(4): 1116-1125.

Bain J 1977. Hylurgus ligniperda (Fabricius) (Coleoptera: Scolytidae). Forest and Timber Insects in New Zealand. No. 18. Forest Research Institute/New Zealand Forest Service, Rotorua, New Zealand.

Barak AV, Elder P, Fraser I 2011. Lowtemperature methyl bromide fumigation of emerald ash borer (Coleoptera: Buprestidae) in ash logs. Journal of Economic Entomology 104(1): 69-74.

Bond EJ 1975. Control of insects with fumigants at low temperatures: response to methyl bromide over the range $25^{\circ}$ to $-6.7^{\circ} \mathrm{C}$. Journal of Economic Entomology 68(4): 539-542.

Bond EJ, Buckland CT 1976. Control of insects with fumigants at low temperatures: toxicity of mixtures of methyl bromide and acrylonitrile to three species of insects. Journal of Economic Entomology 69 (6): 725-727.

Brockerhoff EG, Jones D, Kimberley MO, Suckling DM, Donaldson T 2006. Nationwide survey for invasive wood-boring and bark beetles (Coleoptera) using traps baited with pheromones and kairomones. Forest Ecology and Management 228: 234-240.
Haack RA 2001. Intercepted Scolytidae at U.S. ports of entry: 1985-2000. Integrated Pest Management Reviews 6(3): 253-282.

Lee JC, Haack RA, Negron JF, Witcosky JJ, Seybold SJ 2007. Invasive bark beetles. US Forest Service. Forest Insect \& Disease Leaflet $176.12 \mathrm{p}$.

Ministry for Primary Industries 2012. Forest Products Exports Standards - Phytosanitary Requirements of China. http://www. biosecurity.govt.nz/exports/forests/ standards/china.htm\#logs (accessed 31 January 2013).

New Zealand Ministry for the Environment 2011. Annual Ozone Protection Act Report, Amendment to the Ozone Protection Act, 1996. Wellington. $56 \mathrm{p}$.

New Zealand Environmental Protection Authority 2011. Methyl Bromide: a reassessment of methyl bromide and its formulations. Decision - Amended Version (17 June 2011) (pdf). New Zealand Environmental Protection Authority, Wellington. http://www.epa.govt. $\mathrm{nz} /$ search-databases/Pages/applicationsdetails.aspx?appID=HRC08002\# (accessed 21 May 2013).

Plant Protection Station, MAFF Japan 2011. Import timber quarantine guidelines. Critera of disinfestation method. http:// www.pps.go.jp/law_active/Notification/ basis /8/55html/55.html (accessed 4 October 2011; translated from Japanese using Google Chrome translation).

Reay SD, Walsh PJ 2001. Observations on the flight activity of Hylastes ater and Hylurgus ligniperda (Curculionidae: Scolytinae) in Pinus radiata forests in the central North Island, New Zealand. New Zealand Entomologist 24: 79-85. United Nations Environment Programme 2010. Montreal Protocol on Substances that Deplete the Ozone Layer. Report of the Methyl Bromide Technical Options Committee, 2010 Assessment. United Nations Environmental Program. UNEP Ozone Secretariat, Nairobi, Kenya. 396 p.

United States Department of Agriculture 2012. Animal and Plant Health Inspection Service, Plant Protection and Quarantine Treatment Manual. Treatment Schedules. U.S. 
Department of Agriculture, Animal and Plant Health Inspection Service, Plant Protection and Quarantine, Washington DC. http// www.aphis.usda.gov/import_export/plants/ manuals/ports/downloads/treatment.pdf (accessed 20 May 2013).

Vincent LE, Lindgren DL 1975. Toxicity of phosphine and methyl bromide at various temperatures and exposure periods to the four metamorphic stages of Trogoderma variabile. Journal of Economic Entomology 68(1): 53-56.
Vincent LE, Lindgren DL 1977. Toxicity of methyl bromide and phosphine at various temperatures and exposure periods to the metamorphic stages of Lasioderma serricorne. Journal of Economic Entomology 70 (4): 497-500.

Yu KY, Chung YW, Lee MH, Jae JW 1984. Study on shipboard fumigation of the imported logs. Korean Journal of Plant Protection 23: 37-41. 